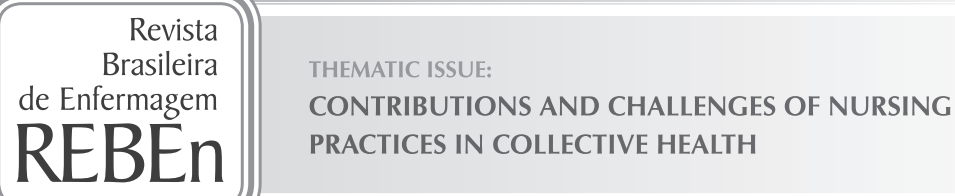

\title{
Social network: evaluation of the support or containment contexts of lesbian mothers
}

\author{
Rede social: avaliação do contexto de apoio ou contenção de mães lésbicas \\ Red social: la evaluación del contexto de apoyo o contención de madres lesbianas
}

\section{Firley Poliana da Silva Lúcio', Paula Daniella de Abreu', Eliane Maria Ribeiro de Vasconcelos', Ednaldo Cavalcante de Araújo'}

' Universidade Federal de Pernambuco, Postgraduate Program in Nursing. Recife, Pernambuco, Brazil.

\section{How to cite this article:}

Lúcio FPS, Abreu PD, Vasconcelos EMR, Araújo EC. Social network: evaluation of the support or containment contexts of lesbian mothers. Rev Bras Enferm [Internet]. 2018;71(Suppl 1):490-5. [Thematic Issue: Contributions and challenges of nursing practices in collective health] DOI: http://dx.doi.org/10.1590/0034-7167-2017-0419

Submission: 06-12-2017 Approval: 08-09-2017

\begin{abstract}
Objective: To evaluate the social network of lesbian mothers, from the social contexts of support or restraint. Method: Descriptive, exploratory study, of qualitative approach, based on the theoretical reference of Social Network, with eight lesbian mothers selected through Snowball technique, using semi-structured interview. Data analysis was performed with IRAMUTEQ software, through Similarity Analysis. Results: The social network is configured as: 1) Emotional distance and non-acceptance of motherhood by the family members - primary network elements; 2) Interference in the socio-cultural medium for the effectiveness of the mother-child bond - secondary network elements. Final considerations: Social network is grounded on trivialized and negative conceptions that highlight prejudice and disrespect. The discussion of this theme contributes to a greater visibility of those new family arrangements as well as to reduce stigmas e prejudices that pervade the social network components of these women.
\end{abstract}

Descriptors: Nursing Care; Family Nursing; Family Power; Social Support; Female Homosexuality.

\section{RESUMO}

Objetivo: Avaliar a rede social de mães lésbicas a partir do contexto social de apoio ou contenção. Método: Estudo descritivo, exploratório, de abordagem qualitativa, ancorado no referencial teórico Rede Social, com oito mães lésbicas, selecionadas por meio da técnica Snowball, mediante entrevista semiestruturada. Realizou-se a análise dos dados pelo software IRAMUTEQ pela Análise de Similitude. Resultados: A rede social configura-se em: 1) Distância afetiva e não aceitação da maternidade pelos familiares - elementos da rede primária; 2) Interferências no meio sociocultural para efetivação do vínculo mãe e filho - elementos da rede secundária. Considerações finais: A rede social está alicerçada nas concepções banalizadoras e negativistas que destacam o preconceito e o desrespeito. Tratar deste tema é contribuir para maior visibilidade a esses novos arranjos familiares, bem como para diminuir os estigmas e preconceitos que permeiam os elementos componentes da rede social dessas mulheres.

Descritores: Cuidados de Enfermagem; Enfermagem Familiar; Poder Familiar; Apoio Social; Homossexualidade Feminina.

\section{RESUMEN}

Objetivo: Evaluar la red social de madres lesbianas desde el contexto social de apoyo o contención. Método: Estudio descriptivo, exploratorio, de abordaje cualitativo, anclado en el referencial teórico Red Social, con ocho madres lesbianas, seleccionadas por medio de la técnica Snowball, de acuerdo con la encuesta semiestructurada. Se realizó el análisis de los datos por el programa (software) IRAMUTEQ por el Análisis de Similitud. Resultados: La red social se configura en: 1) La distancia afectiva y no la aceptación de la maternidad por los familiares - elementos de la red primaria; 2) Las interferencias en el medio sociocultural para la efectuación del vínculo madre e hijo - los elementos de la red secundaria. Consideraciones finales: La red social está basada en las concepciones banalizadoras y negativistas que subrayan el prejuicio y la falta de respeto. Tratar de este tema es aportar para la mayor visibilidad a esos nuevos arreglos familiares, así como para disminuir los estigmas y prejuicios que permean los elementos componentes de la red social de esas mujeres.

Descriptores: Cuidados de Enfermería; Enfermería Familiar; Poder Familiar; Apoyo Social; Homosexualidad Femenina.

$$
\text { CORRESPONDING AUTHOR Firley Poliana da Silva Lúcio E-mail: polianalucio2014@gmail.com }
$$




\section{INTRODUCTION}

Women's emancipation was constructed from claims against the oppressive and exclusionary social system. Feminism has marked the political, social, and ideological movements of fighting for equal rights, in favor of women's protagonism. Thus, it encompassed legal and relational axes of expression, starting the discussion from freedom as the women's foundation for the domain over their own body, sexuality, and destiny ${ }^{(1)}$.

Discussions on LGBT parenting reach global proportions. An emerging topic is the constitution of planned lesbian families, in which the couple decides to have a child through artificial insemination, a phenomenon that is also called lesbian "baby boom." However, heteronormativity is preponderant in social relations, being reflexes of this marginalization of sexual minorities the discriminatory attitudes and verbalizations, especially in workplaces and health services ${ }^{(2)}$.

In Brazil, reproductive and family planning of lesbian women ensures the right to motherhood. Techniques of artificial insemination and in vitro fertilization are provided by the Brazilian Unified Health System (Sistema Único de Saúde SUS) and are independent of an infertility diagnosis ${ }^{(3)}$.

In a context of integral health care and social visibility, the lesbian identity constitutes a range of possibilities to build emotional ties, behaviors, and feelings which are not limited to the sexual expression. New constitutions, functionality, and family dynamics aggregated parenting arrangements of lesbian mothers, and guide the construction of affective bonds, which demand challenging social roles of respect to human rights $^{(4)}$.

Dynamically, social networks involve interpersonal relationships and exert containment or support functions. The central core is the family, since it represents, for the individual, the first contact with affective and relational experiences. In this system, vulnerability does not have a static character, but it will differ according to challenges and resources available face the needs or problems ${ }^{(5)}$.

Network interventions require knowledge on the existing capillarity among relational ties. Understanding the family structure, and valuing social context, bonds, and relationships, unveils peculiarities that transcend the representations and constitute new paradigms for the lesbian identity.

\section{OBJECTIVE}

To evaluate the social network of lesbian mothers, from the social contexts of support or containment.

\section{METHOD}

\section{Ethical aspects}

Data presented here are part of a thesis, developed in the Graduate Program in Nursing of the Federal University of Pernambuco (UFPE), whose project was approved by the Research Ethics Committee of the Center for Health Sciences of the Federal University of Pernambuco. The study is in accordance with Resolution No. 466/2012 ${ }^{(6)}$, following the ethical principles of autonomy, beneficence, non-maleficence, justice, and privacy.

\section{Type of study}

This study is characterized as a descriptive, exploratory research, of qualitative approach, based on the theoretical reference of Social Network.

\section{Methodological procedures}

\section{Study scenario}

The study location was the city of Recife, capital of Pernambuco, which proved to be a focal environment for the residence of lesbian mothers. Such location was elected due to the fact of the sampling being collected by Snowball technique. The participants, who composed the research sample, inhabited in any locality in the city of Recife (PE). The households are a more conducive environment for the interviews since they are familiar to the participants, which favored the freedom in expressing ideas and feelings. For this reason, these were the locations chosen by the respondents.

\section{Data source}

The sample was composed of women above 18 years, residents in the city of Recife (PE), Brazil, and who had experienced the motherhood. As exclusion criteria were considered: being far from the city of Recife (PE), Brazil, due to illness or other reasons; and not answering to the contacts (phone, email, and others). To select the used sample, the Snowball chain sampling, which is a variation of the samplings by convenience and saturation, was used.

\section{Data collection and organization}

The production of data occurred in the period from April to June 2016, from semi-structured interviews conducted with lesbian mothers in their households. We performed a total of eight encounters, with a mean duration of 1 hour and 10 minutes each.

Recruitment of participants was through chain-referral sampling (Snowball). The choice for such technique is justified by the need for identifying the research subjects since they present characteristics of difficult social recognition. The first step was the selection of key people or "seeds," proceeding to the indication of other participants, who were contacted and added to the sample ${ }^{(7)}$

Women who identify themselves as lesbians, denominated "seeds," indicated the others who took part in the study. According to the steps recommended by the Snowball technique, firstly we contacted the coordinator of the Municipal Center for Citizenship Reference of Lesbians, Gays, Bisexuals, Transvestites, Transsexuals, and Transgenders (LGBT). On that occasion, the study was explained and her contribution was requested. The Coordinator came into contact with the President of the Lesbian Women Committee (COMLÉS), reinforcing and highlighting her support for the research on the subject. Members of the COMLÉS were invited by the President, and one of them requested participation, being named a seed-individual; she was not part of the sample composition, having the function of indicating other participants. These participants integrated, then, the recruitment level called "wave"; at the end of each interview, each one in the wave had the incumbency of suggesting other possible participants. 


\section{Data analysis}

Data analysis was performed with the Software Interface de $R$ pour les Analyses Multidimensionnelles de Textes et de Questionnaires (IRAMUTEQ), version 0.7 alpha 2. For this research, the Similarity Analysis was selected, which is based on the theory of graphs. Such analysis assisted in the identification of co-Occurrences in the representation structure, and its results brought indications of connectedness among the words. In the textual statistical analysis performed through IRAMUTEQ, we obtained a similarity tree of the free associations, guided by the hierarchization of connections values among terms and their adjacencies, for each category identified $^{(8)}$.

\section{Validity and reliability/Rigor}

Methodological rigor ${ }^{(9)}$ was ensured through regular meetings with the team members involved in the research. Sampling methods, generation and interpretation of data were discussed. The interviews were transcribed over the period of data collections, as a record of the research process $^{(10)}$. The chosen method for data processing and analyzing allowed categorization and connection ${ }^{(11)}$, congruent with the critical realistic methodology and with the constructivist epistemology that underpins this study whose conduct and report were done in accordance with the Consolidated Criteria for Qualitative Studies Reports ${ }^{(12)}$.

\section{RESULTS}

Interviewees were in the age group from 28 to 46 years old, with a mean age of 37.5 years old. Five lived in consensual unions and three were married. Regarding educational level, five possessed undergraduate degree and three held high school degree. We highlight that seven had various types of occupation/profession (social scientist, psychologist, selling promoter, pedagogue, administrator, and community health agent) and only one interviewee was dedicated to housekeeping.

Regarding monthly family income, all the participants survived with three to four minimum wages; as for religiosity, they presented several beliefs (candomblé, Catholicism, kardecism, and agnosticism), with a representation of $25 \%$ each.

The analyzed textual corpus evidences, as it can be noted in Figure 1, the interface of similarity analysis results, with the identification of co-occurrences among words spoken by the study participants, and the indications of connectedness among terms (no, motherhood, rejection, child, mother, new, knowledge, family, difficult, and discrimination). This assists in determining the structure of the representational field of lesbian mother's social network, starting from the construction of interpersonal bonds under the current heteronormative context.

After the analysis, it is noteworthy that the construction of the co-occurrence tree, with the information reported by the interviewees, addressed aspects concerning the motherhood process (positive and negative experiences). Through these experiences, it is possible to identify how is configured the social network of the woman who assumes her lesbianism and decides to exercise her motherhood. Therefore, we can highlight, as primary network elements, the Emotional distance and non-acceptance of motherhood by the family members; and, as secondary network elements, the Interference in the socio-cultural medium for the effectiveness of the motherchild bond. Thus, the configuration of the networks reported by them presents the bond and its development, according to the way these women integrated to the social context.

\section{DISCUSSION}

For understanding how is structured the social network of women who assume their lesbianism and experience motherhood, it is necessary to understand that such network is a set of relationships that these women build, from which they maintain their own social identity. Thus, it is through the bonds established on that network that the social support will flow.

A weakening on any of these elements that comprise the network can lead to situations of social vulnerability, relational frailty, and precarious family bonds. Given this context, when it comes to homoparental families, the primary support network tends to change accordingly to sociocultural context to which the family is inserted, since this composition is not part of the standardized familiar arrangement. 
Emotional distance and non-acceptance of motherhood by the family members

Family is the center of the primary social network, since it is the first reference of culture and connection that the individual establishes. Thus, from the emotional ties skills will be developed, and also languages, and competencies required to cope with the social environment. Moreover, it is when the functions of education, care, and protection are performed ${ }^{(5)}$.

The functioning of families with a homoparental structure does not relevantly differ from heterosexual ones; however, these families are a target of homophobic stigma. Teenage children of lesbian mothers eventually suffer from moral harassment and bullying, making them more susceptible to psychosocial damages. This reflects on the individual as depressed status, aggressive behavior, and distancing regarding their mothers ${ }^{(13)}$.

In this teen years in which my children are, it is difficult for them to relate to me [...] even due to my family being very discriminatory, I think that, in a certain way, today they don't accept me anymore. They don't accept anymore that I'm married to a woman, they don't want to live with me anymore. (Interview 06)

I've never had a good relationship with my mom, and unfortunately, I passed that kind of relationship on to my daughter. Motherhood was a turning point in my life. My daughter was what filled me inside, she was that comfortable furniture in the middle of that empty room, she was like a rescue, and in this relationship of love and hate we have, she is my everything. (Interview 05)

The reports denote that frailties on the family of origin may adversely reflect on the family dynamics between homosexual couples and their children ${ }^{(14)}$. The normative social organization reflects the patriarchal family model, expressed in Brazil since the colonization period; this family structure comprised and led by the "father" represents social prestige, and those who differ from this standard are rejected by society, from the hetero-sexist historical and cultural influence. Moreover, low social support, especially the absence of a strong family structure, increases the chances of insecurity, inability to perform functions, and seclusion, making it likely for these women to suppress their desire to be a mother.

Despite my role as a mother being taken from me due to my parents' conservative way of thinking, I still love them and I'm always ready to receive them when they call me because I respect their position as well as I would like to be respected. If that's how they think it's best, I respect it completely, even though it hurts me deeply. (Interview 06)

Primary social network dynamics consist in producing information flows and propagating internal forces to the points of greatest load, then in leveling them ${ }^{(5)}$. Thus, the influence of the heteronormative social model might result in personal conflicts, and generate family or social tensions. However, studies show complicity in relationships of homoparental couples regarding everyday activities and family decision-making, cooperation with domestic services, equal financial contribution, and joint participation in the care and education of the children. This evidences the binding construction of support and reciprocity ${ }^{(14-15)}$.

I never spoke openly about my sexual orientation, we are a reserved couple, we are not out to the society, our friendship circle is restricted. It is like if for the society, for the boys' school, co-workers and family, I were a single mom; but no, I have a companion that helps me greatly with the boys' education. (Interview 03)

Despite the homophobia and the majority discourse being grounded in "normality" patterns, acting in the society by legitimizing the patriarchal family structure, and leading to conservative positions that tend to characterize homoparental families as a sign of abnormality, these arguments are strongly linked to the elements that compose the secondary network. Such affirmation translates into the society disregard of the possibility of two women having a child, whether through biological method (artificial insemination) or adoption.

Interference in the sociocultural medium for the effectiveness of the mother-child bond

Network interventions aim the redirecting from a stage of dependency to one of autonomy, in the individual or community levels. For such, family, kinship, neighborhood, and work relationships establish connections with secondary social networks: institutions, market and third sector organizations, in order to outline long-term or emergency interventions ${ }^{(5)}$.

Social, health, and educational services are grounded in promoting citizenship and integrality. Thus, the strengthening of the bond between individuals and social institutions is fundamental for the resolution of problems. The accountability of health professionals on the network requires an equal and longitudinal approach of effective support, bonding, and dialogue.

My gynecologist doesn't even know I'm lesbian, I never had an opening to tell her, so she doesn't instruct me correctly, I don't feel safe to speak, she hasn't asked me about my sexual orientation ever. I guess she thinks I'm heterosexual. She keeps telling me to find a boyfriend, even with me going to the appointments with my partner. (Interview 02)

It is noteworthy that the essentially clinic and technical assistance suppresses the real demands in health. On the other hand, cultural competence is required from professionals in the integral attendance to lesbian women, especially from those in public and private health services. Specialized gynecology care should offer reception, bonding, and care alternatives for the sexual and reproductive health of women and couples, according to the gender identity and sexual orientation.

In the field of health, the reception and the language used during attendance, in a discriminatory manner, result in frailty or loss of the connection among these women and health institutions ${ }^{(16-17)}$. Such a fact create obstacles in the dialogue 
between the women and health professionals since they feel intimidated that revealing their sexual orientation can lead to suffering some type of exclusion. The communication among these stakeholders results in support or restraint. This latter, sometimes, begins from the first contact between mothers and health professionals.

Heteronormativity refers to biological-related behavioral patterns through conceptions that were historically built and naturally incorporated to male and female contexts. Considering this side of the issue, the educational scope, language plays an important role because it contributes to behavior standardization, often in an exclusionary manner, directly interfering in the subject moral formation since the language has the power to make several actions heteronormative.

We don't have an education that think from every sexual orientations in an inclusive manner, but an education that thinks our sexual orientation in an exclusive manner. My lesbian motherhood influences in this cultural education I bring it to my daughters because is an important process for the subject constructions; after all, from the moment I have at home a mom who is a lesbian, how can I discriminate another person for also being lesbian? (Interview 01)

Given what was exposed in the previous report, the educational field as an heteronormative space can become a confrontational environment for the lesbian woman insertion, considering the existing binary regulations. Although the school is not the only one responsible for explaining or defining the diverse social identities, it is important to highlight that its actions on the subjects assume the value of absolute truth.

The strengthening of bonds within the family affects the critical and reflective social constructions of possible forms of relationship and family structure ${ }^{(4)}$. Thus, an education based on open dialogue between lesbian mothers, their children, and the school environment is essential, for resulting in the formation of a youth that respects the diversity.

\section{Study limitations}

We understand that the phenomenon under study is inserted in a historical and assistance context marked by stigma and prejudice, which made it difficult, in some interviews, for the patient to explain the configuration of their social network in more details. Another limitation was due to the Snowball technique, which does not guarantee representativeness.

Contributions to the field of nursing, health, or public policies

The understanding of the social network has potential to enable network interventions by the multi-professional health team involved in the health/disease process, since the work of a strong social network can promote, in lesbian mothers, changes from the dependency status to one of autonomy.

\section{FINAL CONSIDERATION}

We consider that the evaluation of the social network of lesbian mothers allowed understanding the social relations of support or restraint, faced with interpersonal relations. The bonds and ties between these women and the social, health, and educational services evidenced the social constructions of gender, and of patriarchal and binary sexual orientations.

It is necessary to overcome prejudice and disrespect in the various segments of the network, for contributing with the visibility of those mothers within new family arrangements and, consequently, reduce the stigmata that permeate these women's social network.

Understanding the social network could subsidize interventions of the multi-professional health team, starting from the attribution of responsibility, and support of the stakeholders involved in the health/disease process. The social work demands social responsibility for the strengthening of emotional, presential, instrumental, informational supports, and self-support, to promote changes in the dependency state of lesbian mothers, leading to one of autonomy.

\section{REFERENCES}

1. Winter S, Diamond M, Green J, Karasic D, Reed T, Whittle S, et al. Transgender people: health at the margins of society. Lancet [Internet]. 2016[cited 2017 Mar 10];388(10042):390-400. Available from: http://dx.doi.org/10.1016/S0140-6736(16)00683-8

2. Costa PA. Portuguese attitudes toward homosexual parenting. Psicol Reflex Crit[Internet]. 2013[cited 2017 Mar 10];26(4):790-8. Available from: http://www.scielo.br/pdf/prc/v26n4/20.pdf

3. Brasil. Ministério da Saúde. Instituto Sírio-Libanês de Ensino e Pesquisa. Protocols of Primary Care: Women's Health Care [Internet]. Brasília: Ministério da Saúde; 2016[cited 2017 Mar 10]. Available from: http://bvsms.saude.gov.br/bvs/publicacoes/ protocolos_atencao_basica_saude_mulheres.pdf

4. Lira AN, Morais NA, Boris GDJB. The (in)visibility of female homoparental experience: between prejudice and overcomings. Psicol Cienc Prof[Internet]. 2016[cited 2017 Mar 10];36(1):20-33. Available from: http://www.scielo.br/pdf/pcp/v36n1/19823703-pcp-36-1-0020.pdf

5. Sanicola L. As Dinâmicas de Rede e o trabalho social. São Paulo: Veras; 2015.

6. Brasil. Conselho Nacional de Saúde. Resolução 466, de 12 de dezembro de 2012 [Internet]. Brasília: CNS; 2014 [cited 2017 Mar 10]. Available from: http://bvsms.saude.gov.br/bvs/saudelegis/cns/2013/res0466_12_12_2012.html

7. Sampierre RH, Collado CF, Lucio MPB. Metodologia de RESEARCH. 5a ed. Porto Alegre: Penso; 2013. p. 401-12. 
8. Camargo BV, Justo AM. IRAMUTEQ: a free software for analysis of textual data. Temas Psicol [Internet]. 2013 [cited 2017 Mar 10];21(2):513-18. Available from: http://pepsic.bvsalud.org/pdf/tp/v21n2/v21n2a16.pdf

9. Sandelowski M, Barroso J. Reading qualitative studies. IJQM [Internet], 2002[cited 2017 Mar 10];1(1):74-108. Available from: https://journals.library.ualberta.ca/ijqm/index.php/IJQM/article/view/4615/3764

10. Birks M, Mill J. Grounded theory: a practical guide. London: SAGE Publications Inc; 2011.

11. Maxwell JA, Miller B. Real and virtual relationship in qualitative data analysis. Maxwell JA, editor. A realist approach for qualitative research. London: SAGE Publications Inc; 2012. p. 109-25.

12. Booth A, Hannes K, Harden A, Noyes J, Harris J, Tong A. COREQ. Consolidated Criteria for Reporting Qualitative Studies. In Moher D, Altman DG, Schulz KF, Simera I, Wager E, (Eds.). Guidelines for reporting health research: a user's manual. Oxford: John Wiley \& Sons Ltd; 2014. p. 214-26.

13. Gelderen LVR, Bos HMW, Gartrell NK. Dutch adolescents from lesbian parent families: how do they compare to peers with heterosexual parents and what is the impact of homophobic stigmatization? J Adolesc [Internet]. 2015[cited 2017 Mar 10];40:6573. Available from: https://dx.doi.org/10.1016/j.adolescence.2015.01.005

14. Meletti AT, Scorsolini-Comin F. Marital relationship and expectations about parenthood in gay couples. Psicol Teor Prát [Internet]. 2015[cited 2017 Mar 10];17(1):37-49. Available from: http://editorarevistas.mackenzie.br/index.php/ptp/article/view/6509

15. Walsh F. Family normative processes: diversity and complexity. 4 ed. Porto Alegre: Artmed; 2016.

16. Wojnar DM, Katzenmeyer A. Experiences of preconception, pregnancy, and new motherhood for lesbian nonbiological mothers. J Obstet Gynecol Neonatal Nurs [Internet]. 2014[cited 2017 Mar 10];43(1):50-60. Available from: http://dx.doi. org/10.1111/1552-6909.12270

17. Dahl B, Malterud K. Neither father nor biological mother: a qualitative study about lesbian co-mothers' maternity care experiences. Sex Reprod Healthc [Internet]. 2015[cited 2017 Mar 10];6(3):169-73. Available from: http://dx.doi.org/10.1016/j. srhc.2015.02.002 